\title{
WhatsApp-Mediated Language Teachers' Reflection of Classroom Practice: Experience of Indonesian Context
}

\author{
Agus Prayogo \\ UIN Walisongo Semarang, Indonesia \\ e-mail:agus.prayogo@walisongo.ac.id \\ Lulut Widyaningrum \\ UIN Walisongo Semarang, Indonesia \\ e-mail: lulut.widyaningrum@walisongo.ac.id
}

\begin{abstract}
:
This qualitative case study examines language teachers' reflective practice mediated by WhatsApp application and addresses the topics mostly reflected in the eight topics of classroom practice and the problems faced. A total of 537 entries of chats written, the most common topic of reflection entries is about general teaching approaches. Time restraint and writing chats in English become significant problems of the reflective practice. The practice has provided an online environment that lets teachers interact and share with colleagues to construct knowledge and evaluate teaching practice that beneficial for teacher professional development. Teachers have gained benefits from online reflection collaboration with other teachers, but most of them take into account the need for an online reflection setting that gives freedom to use the language that they are comforted with.
\end{abstract}

Keywords: Classroom practice, Collaboration, Reflective Practice, WhatsApp

\section{Introduction}

A teacher should always assess and examine his or her teaching practice continuously. Such evaluation is crucial for developing a teacher's competence in his or her professional role. Phillips (2008) has mentioned the need for teacher professional development to increase and maintain teachers' quality. They can do some activities either formally or informally, one of which is doing the reflective practice. Reflective practice is a fundamental part and effective option for professional development. It provides teachers with an opportunity to reflect different activities, develop a deeper understanding of their teaching, assess their professional growth, develop informed decision-making skills, and become proactive and confident in their teaching (Chien, 2013; Farrell, 2008; Murray, 2010). In English language teaching setting, studies on 
reflective practice have shown the importance of reflection for language teachers by employing different techniques and tools (Abednia et al., 2013; East, 2014; Ford, 2016; Oakley, Pegrum, \& Johnston, 2014). Based on all those practices, findings indicate that all teachers, both preservice and in-service teachers, feel that they can take benefit from practising reflecting on various aspects (Farrell, 2016).

Teachers can engage in reflective practice in both conventional ways and technology-oriented tools (Burhan-Horasanlı \& Ortaçtepe, 2016). Some studies have investigated the online reflective practice tools such as Blog and Web 2.0 (Anwaruddin, 2015; Nambiar \& Thang, 2016), mobile technology (Pack, 2014), and Moodle online discussion (Burhan-Horasanlı \& Ortaçtepe, 2016). However, in this study, we examine the reflective practice through smartphone application considering that mobile smartphones, with numerous applications offered, have become inseparable parts of modern life nowadays. One of the smartphone benefits is the ability to exchange text and multimedia among its users through free messaging apps (Pollard, 2015). WhatsApp is one of the messaging applications which is the most successful one on a global scale (Yeung, 2013), so no wonder that many people in all ages widely use it including in Indonesia. Either individual or group, including teachers, may use the application depending on the purpose. It has been proved that some WhatsApp groups are made by a particular group of teachers to share, communicate, and exchange information. With such widespread use, the application offers teachers'reflective collaboration on their classroom practice in the form of dialogic messaging which is beneficial for professional development.

\section{Literature Review}

\subsection{Reflective Practice}

Reflective practice has been called reflection or reflective teaching (Burhan-Horasanlı \& Ortaçtepe, 2016) that originates from Dewey (1933) as a systematic process to solve the problem through teachers' purposeful thought settling in a specific event or situation. Then, scholars have defined it differently so that it is difficult to present a single definition. The concept begins from the concept of reflection as (Chien, 2013, p.132) summarises that "reflection involves teachers' thinking analytically about their past and current teaching beliefs, experience, and practice". However, Farrell (2012) makes a metaphor of reflection as teachers' compass that may help to understand the reflection clearly. The compass illustrated direction guide for teachers "to stop, look, and discover where they are at that moment and then decide where they want to go (professionally) in the future" (p. 7). Consequently, teachers require explicit purposes of reflective practice that can keep their tracks although achieving them may become not easy work.

In English Language Teaching field, Pennington (1992) suggests that the purposes of reflective practice are to develop the process and outcomes of classroom activities and to improve the motivation and confidence of both teachers and students. In line with these purposes, Murphy (2014) adds that reflective practice provides extensive understanding toward the processes of teaching and learning; owns knowledge on various teaching strategies and activities (Orlova, 2009) that can be employed in the classroom; builds theories on appropriate teaching practice that must be carried out; and establishes a variety of learning settings and occasions for students. To attain these purposes effectively, Chien (2013) recommends that teachers and practitioners should invest time and resources with a sustained commitment in order to hold the first practice 
of reflection. Such a commitment must become the primary support in teacher education so that reflective practice is not just as a routine.

Reflective practice can be conducted in different approaches and forms such as action research, diaries and journal, and teacher development group (Borg, 2001; Farrell, 2008a); either conventional such as autobiography and observation or technology-oriented tools such as blog and Moodle that improve the reflection's depth and breadth (Burhan-Horasanlı \& Ortaçtepe, 2016). Writing journal, for example, has challenged teachers as it provides benefit to enhance self-awareness, develop personal understanding, reflection and reflecting skill (Abednia et al., 2013), and facilitates students' learning with its breadth and depth (Bain, Ballantyne, Packer, \& Mills, 1999). Chien (2013) and Brock, Wong, \& Yu, (1993) propose various topics and issues of classroom practice for journal and diary such classroom management, general teaching approach, rationale for specific teaching approaches, teaching strategies, teacher decision making, students' behavior, teacher-student relationship, students' performance, students with special needs and problem, and instructional content.

The writing of reflection for classroom practice requires teachers to write their story of what has been experienced. Narrative inquiry is "a way of thinking about experience" (Connelly \& Clandinin, 2006, p.375) in the form of "a conception of the phenomenal world in which experience is mediated by the story" (Xu \& Connelly, 2009, p. 221). Connelly \& Clandinin (2006) mention that narrative inquiry comprises three commonplaces or three-dimensional space namely temporality, sociality, and place. Temporality refers to the temporal transition where events and people exist, in which narrative inquirer is needed to consider the past, present, and future of an event, person, or object. In this context, teachers' past experience, present actions, and future plans establish knowledge. Sociality is about both personal conditions and social conditions. The former indicates the feelings, attitudes, and moral dispositions of a person toward events, while the latter includes the context of administration, policy, and community. Place refers to "the specific concrete, physical and topological boundaries of place or sequences of places where the inquiry and events take place" (p. 480). Studies that use three-dimensional narrative inquiry strands show that reflective practice helps a teacher practice to examine his or her assumption and belief that construct knowledge and teaching skill; this may also assess the future practice and influence the decision making for effective teaching practice (Chien, 2013; $\mathrm{Xu} \& \mathrm{Liu}, 2009)$. Through thinking the way of three-dimensional inquiry, teachers need to consider how their prior experiences and relationships help them engaged in contextual and relational knowledge (Mitton-Kükner, Nelson, \& Desrochers, 2010).

\subsection{Collaboration in Reflective Practice}

Reflective practice has two fundamental components namely input and collaboration or collegial support (Martínez, 2018). Collaboration is "a major tenet of action learning, with small teams or 'sets' working together on tasks or problems” (Ellis \& Phelps, 2000, p. 28). Collaboration provides social support and elaboration from others to build and co-construct arguments and ideas through reflection (Newell, 1996). With any collaborative reflective practice made, (Farrell, 2008a) suggests that peers can challenges and support thinking because they can both complement each other's strengths and compensate for each other's limitations. Having peers for reflection enables teachers to achieve outcomes that are not possible for an individual. 
Collaborative reflective practice can be conducted by a direct meeting or online. Teachers may collaborate through teacher development group or sharing the journal or diaries to other teachers directly. Newell (1996) study reveals that face to face collaboration with other teachers with different experience and background helps to expand teacher's new viewpoint and understanding, push to define perspectives and make aware of classroom experiences. Kabilan (2007) points out phases of reflection with others namely examining self of his or her practice and examining others' practice. The former is performed by writing teachers own reflections and reading others' critiques of his or her practices, while the latter is conducted by giving critics and suggestion to other practices.

\subsection{Online Reflective Practice}

People around the world have enjoyed the extensive use of the internet. Mobilephone is one of the devices that use the internet to operate the system such as Android, "an operating system for mobile devices which includes the Linux-based operating system, mildware and applications", in which later becomes an open platform to create applications (Musahrain, 2016, p. 308). Applications in Android provide chat message technological tools that enable people to communicate either in person or in a chat group. Teachers can use that form of online communication as a reflective practice where they discuss, criticise, and share about everything. Some studies expose practical tools of teachers' reflective practice and professional development through online discussion platforms (Jones \& Ryan, 2014; Kabilan, Adlina, \& Embi, 2011; Pedro, Abodeeb-Gentile, \& Courtney, 2012; Romano, 2008; Tsang, 2011).

Tsang (2011) study reveals explicitly that online reflective group discussion demonstrates the potential to develop and evolve professionals. Besides, Jones \& Ryan (2014) emphasise that an online discussion is a useful tool for creating reflective opportunities focusing on classroom practice such as classroom management and effective teaching strategies. The online community discussion involves teachers in the kind of reflection that address problems through ideas as a solution. The present study builds on these investigations with broader aspects of teachers' classroom practice as previously stated.

\section{Research Methodology}

This study is a qualitative case study. The case study allows researchers exploring in depth a process, activities, or events (Creswell, 2009) so the detail can be used to address the question of how and why (Yin, 2003). The case related to time and activity allows the researchers to analyse detailed information collected within a specified period. The study aims to explore teachers' online collaboration through WhatsApp of online community and address the topics mostly reflected in the classroom practice, and the problems or challenges that teachers face in writing reflection. The reflection topics have been limited into eight topics proposed by Brock, Wong, \& $\mathrm{Yu}$, (1993) such as the Classroom Management, General Teaching Approaches, Rationale for specific teaching approaches, Students' responses, Teacher and students relationship, Classroom Interaction, Teacher decision making, Specific "problem" student. The reflections are recorded in the narrative process in the form of chat message of teaching reflection of classroom practice written collaboratively by teachers. The use of narrative inquiry is intended to collect a small corpus of narratives so that generalisation can be made (Xu, 2014). 


\subsection{Participants and Context}

The participants of this study are teachers teaching General English Two subject at the Intensive Language Program. In this program, General English consists of two levels with a different focus. General English One focuses on listening and speaking skills while General English Two focuses on reading and writing skills. Twenty-two teachers are teaching the subject, so twentytwo consents are distributed as well. Among those teachers, seven teachers return the consent and agree to participate at first. However, a teacher decides to dismiss the participation due to some reasons so that the number of participants in the study is only six teachers. The participants are three females, and the other three are males with different background of education. Two teachers are majoring in English Education, two teachers are majoring in English Linguistics, one teacher is majoring in English Literature, and one of them in is majoring in Islamic Studies. The participants are named with T1, T2, T3, up to T6 based on the number of the teachers.

The participants teach the course at different faculties and majors at a state Islamic university in Semarang, Indonesia, including faculty of Dakwah, Islamic Law, Islamic Economics and Business, and Social and Political Science in the academic year of 2017/2018. The course is compulsory for all students at the university and organised under the Intensive Language Program. In that program, the course is organised with other language courses such as Arabic and Indonesia. The number of students in each class is around thirty-five to forty students. The class setting is based on the major not based on the placement test. Since the students are not majoring in English and they are at a different level of English skill, teaching them may become a challenge.

\subsection{Data Collection and Analysis}

The data in this study consisted of various sources namely 1) reflection entries of classroom practice which are written in WhatsApp group application and 2) record of interviews. The reflection is written based on classroom practice of English Two course at faculty of Dakwah, Islamic Law, Islamic Economics and Business, and Social and Political Science. Teachers write their reflection in a WhatsApp group that has been created by researchers. They write their reflection after they have completed their class. Then, each of them is free to comment, question, or give feedback. A semi-structured interview protocol is designed to interview teachers and record their opinions on writing reflection of their classroom practice. The interview asks participants to elaborate on their written narratives, and it is conducted in either English or Indonesian language. The reflection entries are taken throughout sixteen meetings of the course. The entries and feedback become the data which are then organized according to the categories, patterns, and topics. However, in classifying the topic of classroom practice, the researcher can face a problem such as a topic belongs to more that one category (Farrell, 2008b) because the teacher writes the same answer to a different question.

\section{Findings}

There are 537 entries of chats written. Among those entries, 183 reflection entries relate to the topics, with 138 feedbacks and questions. So, the total entries relate to this study is 321 entries. The rests deal with the conversation between teachers. The participants can chat different things not only the classroom practice but also information dealing with the Intensive Language Program. In addition, the chats also cover meeting appointment among participants of this 
study as support to the development process. The freedom to write chats other than the suggested topics makes the relationship among teachers closer so that they feel free to give feedback or questions.

The most commonly reported chat topics as the reflection entries is classroom management (42),general teaching approaches (76), rationale for specific teaching approaches (29), students' responses (8),teacher and students relationship (3),classroom interaction (6), teacher decision making (14),specific "problem" student (5). Identification of entries is made to find out which one is the reflection entries, feedbacks, and the ones not related to the study. However, as stated before that the categories made tend to be problematic due to a category may belong to more than one category. Such condition also happens in the study of (Chien, 2013).

\subsection{Classroom Management}

Entries on a classroom management deal with seating or grouping students in activities as written by T3. T3 divides the class into some groups, and each of the group should consist of no more than 5 students (example 1). It seems that this kind of grouping is done often by T3 as stated in the entry (example 2). Another example is written by T5 and T6 who write things to do to manage the classroom and what activity is done after grouping (Example 3) and (Example 4). Grouping is an example of how a teacher manages the class, and it will be continued with the next activities that are categorised into other categories. This entry also relates to teaching strategies as it states specific activities namely vocabulary quiz activity.

Example 1 (T3):

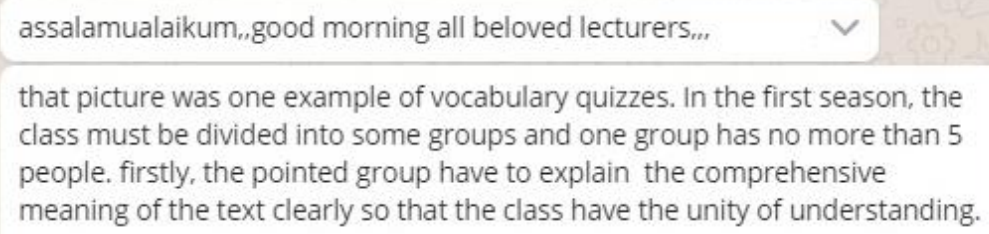

if it is needed, the teacher just give little correction

Example 2 (T3):

i divide the whole class into two big groups

every group must send their 4 delegations in a session,

in one session a let students to explore two texts

$07: 53$

$10: 13$

Example 3 (T5):

In The 1st class on Islamic Education, I made students familiar with word forms and some part of speech (particularly Adj,Noun,Adverb). I made 5 groups of ss based on paragraphs in the text (a group has a paragraph), I then asked them to look for other word forms of words written in the paragraph, and to make example of each (new) word form in a simple sentence. 
Example 4 (T6):

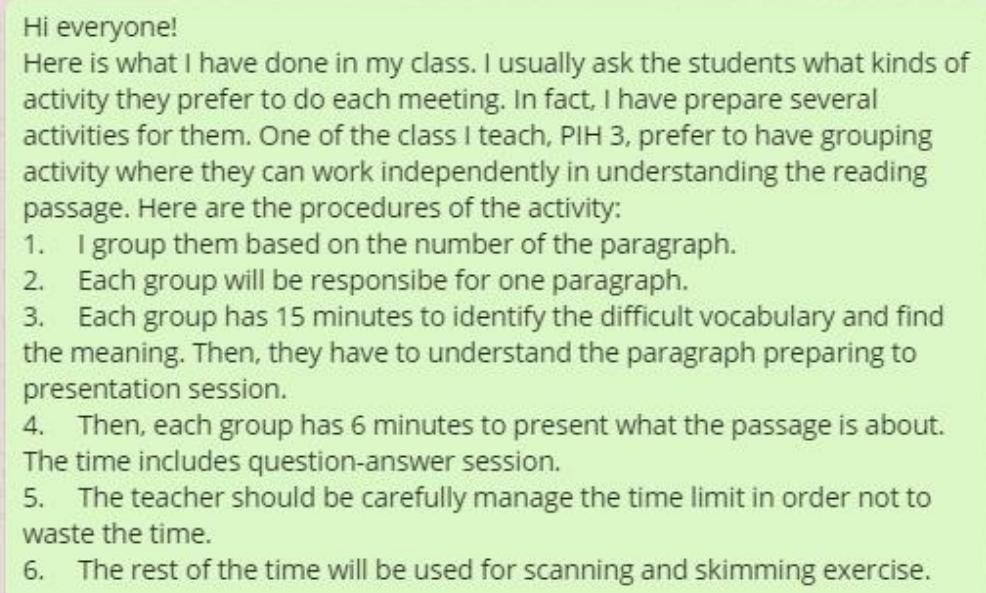

\subsection{General Teaching Approaches and Strategies}

The approaches and strategy chosen by the teacher is the most entry written by the teachers. Almost all teachers write the activities and strategies used in the classroom. T2 posts the example of a strategy used, the mind map concept, in teaching chapter 2 of the book (example 5). T2 post the picture of mind map concept at first. Then, this post invites questions from other teacher asking the guideline of the activity. Then, T2 adds with what should the students do like the activity. The students have known it so they can present the material using the mind map concept (example 7). This explanation has inspired another teacher that he will use the same activity in his class (example 8).

Example 5 (T2)

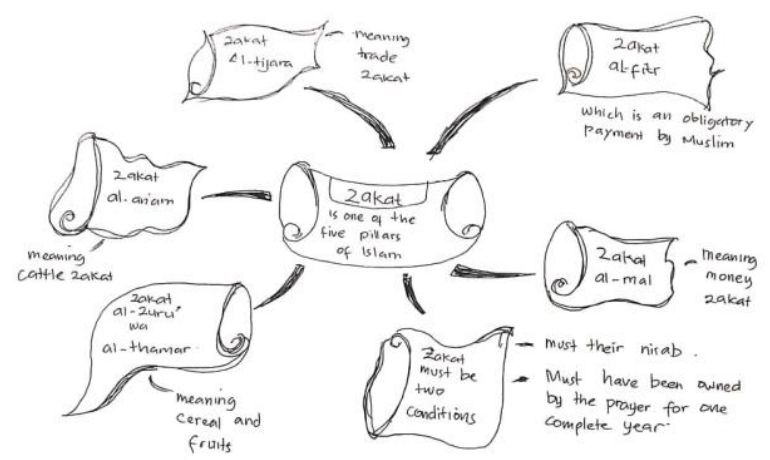

Example 6 (T6):

Wow great bu tar. How do they make the map? Is it based on the paragraph or sth else? Do you tell them guideline to make the map or you let them make it by their own? Many thanks for sharing here 
Example 7 (T2):

Just instructing them to comprehend text $2 \mathrm{n}$ summarize it in the form of concept map by paying attention to the completeness of information $n$ the logical order/link between each part. No example was given. In fact the students had known it. In the class they worked in group of 4, each member presented the map $n$ each group chose 1 map which best represented the text. Two of the chosen one was shared with the whole students $n$ criticised

Example 8 (T5):

This's interesting, Bu. It requires students to comprehend the text. I'm just planning to use the same way when dealing with the reading section.

An example of a teacher who writes chat entry on approaches and strategies is T3 who make vocabulary quiz as the activity. The teacher gives a grid of vocabulary (example 9) with different code such as A for antonym and S for synonym. The activity is moved to more complicated by asking students to come with the definition. There is a special rule given here by T3, and the students must not bring a digital or online dictionary. Instead, they should bring a dictionary book (example 10). There is question dealing with the activity asking about who should decide the vocabulary (example 11) and T3 answer that the teacher should choose and prepare the vocabulary, but the vocabulary must be adjusted with the students' level (example 12). This vocabulary activity is not applied to all units of the book (example 13). This activity has been supported by other teachers such as T5 saying that the activity may help students to understand words from a different point of view such as headword, antonym, synonym, even collocation (Example 14). T2 appreciates the activity as it can be an option to avoid boredom by exploring meaning in a conventional way. Consequently, this strategy facilitates students to learn vocabulary in different forms and various meaning (example 15). However, an important note is stated by $\mathrm{T} 6$ questioning the number of the antonyms and reminding the time management whether or not the meeting adequate for both reading and vocabulary activity (Example 16).

Example 9 (T3):

ISLAMIC DAKWAH
\begin{tabular}{|l|l|l|l|l|}
\hline PRACTICE & STATED & DEFINITION & PUT & RIGHT \\
S & S & S & S & S \\
\hline MOMENT & PLACE & MENTAL & CAPABILITY & CONVEY \\
S & S & S & S & S \\
\hline REQUIREMENT & ATTRACTIVE & PRINCIPLES & IDEA & RESPECT \\
S & S & S & S & S \\
\hline BASIC & FOLLOWER & OPPONENT & REJECT & AGAINST \\
S & S & S & S & S \\
\hline GROUP & HATE & HATE & & \\
\hline$S$ & S & A & & \\
\hline
\end{tabular}




\section{Example 10 (T3):}

before the class have been starting,all the members have to prepare for getting the text meaning, so it is the turn the dictionary will be really important. i recommend all students to use manual or text dictionary. the digital dictionary should be banned ... (4) because the students will not get deeper exploration from digital dictionary, e,g. for the part of speech

the quizzes had two codes in the early text and episode, A means that antonym while S means that synonym,

for further session, the code will be increased, there will be "D" means that simple definition, it requires students' ability to make simple sentence.

\section{Example 11:}

The vocabulary chosen by the students? Or teacher?

\section{Example 12 (T3) :}

the teacher should prepare the word selection, in term of the chosen words would be distributed

by the teachers, mam $10 \cdot 31$

for the special note, sometimes the meaning conquiring for different class may be different because their ability and the background knowledge

\section{Example 13 (T3) :}

of course not mam, based on the previous teaching, maximally i explore 6 chapters,

depend on the class level and situation $10: 51$

may be, some classes needed more special treatment in their writing moment, hehehe, so the writing session would be longer.

\section{Example 14 (T5):}

I think this sort of activity is good for vocabulary building, Bu. Students (Ss) will understand words from different viewpoints, e.g. headword, synonyms, antonyms, parts of speech, examples of correct (or incorrect) usage, and collocations sometimes. 
Example 15 (2):

Sorry for late respon. It s such a great strategy to have vocabulary quiz, sin n anth. There are some more voc quizes may be implemented to avoid boredom of exploring meani $g$ in conventional way. Yours is facilitating your ss to learn forms $n$ meanings variedly

Example 16 (T6):

Bul' .. . it seems that the number of synonyms is more than the antonyms. In my opinion, more antonyms should added. $22: 30 \mathrm{~V}$

I think the teacher should make sure that the meeting will be adequate for vocabulary and reading activity.

T4 decision to ask students not to use online or digital dictionary has made curious other teachers. Some may support, and some may argue that digital and online is the preferable one. Those who agree to with the use of an online dictionary argue that banning it just less helpful for students when the goal is only synonyms or antonym. The teacher even suggests the useful link at www.thesaurus.com to help students gain additional information about the focused vocabulary (example 17). Other options for the use of it, T4 suggest the use of ProDict Indonesia English that provides various part of speech (Example 18).

Example 17 (T1):

It's such a great idea, but to ban the use of digital dictionaries is less helpful

for students (if the goal is synonyms and antonyms), as it is known, the dictionary provided is the english-indonesian dictionary. I usually provide additional suggestions for them to browse thesaurus.com to help them obtain additional information from the focused vocabulary.

Example 18 (T4):

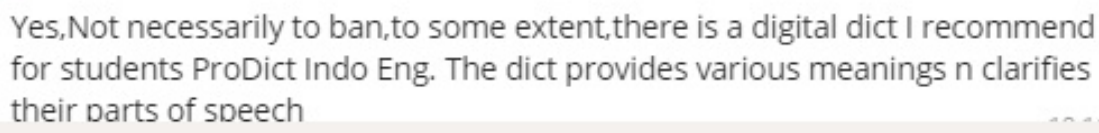

\subsection{The rationale for specific teaching approaches}

Teachers always have reasons for choosing certain approaches and strategies. The rationale stated by teacher T3 in choosing vocabulary activity is the need for participation from the whole class members. In addition, it is hoped that it will avoid students from boredom (example 19). The rationale also expressed when T3 bans the use of either an online or digital dictionary. She argues that using a digital and online dictionary is just an instant way (example 20) that does not help students. Teachers decision to start the course with either reading or writing skill has been a consideration for other teachers. T5 decide to start the teaching with writing skill because he experiences less adequate time to discuss writing material during the course.

On the other hand, writing is considered more complicated skill than reading (example 21). Those are the reason why he decides to start the course with the writing section. T5 is not the 
only one who does so, but T1 also does the same by starting the course with writing section (example 22).

Example 19 (T34):

the reason is that $\mathrm{i}$ gain the whole participation of vocabulary class mam,,

because the text exploration sometimes in my mind would be so boring so i

conclude this quiz will be the best way

Example 20 (T3):

thanks so much, mam, digital dictionary ( in my mind) means that one click dictionary, hehehe

i really prevent students from the use of their "instant way" or their mobile phone,

Example 21 (T5):

Yes, Bu. The reason is that, based on my experience, I don't have enough time to finish the writing section. In fact, there are many toefl issues in it. Also, I think the writing part is more complicated than the reading.

Example 22 (T1):

Yes, pak Agus I did. For the first and the second meeting, I talked about unit 1 and 2 , then on the 3rd meeting, I jumped onto unit 8 , but before that, I gave them home assignment to find example of sentences and fragments from the reading text on unit 1 and 2 . And now, after I discussed unit 8 , about

\subsection{Students' responses}

Not many teachers write reflection entry about students response to the activities they have in the class. The example of the students' response is written by T1 when she teaches paragraphing. The activity makes the students easily understand the reading passage, topic sentence, and supporting sentence (example 23). Another students' response is what T6 writes. He shares that the students ask the same activity because they can work independently in understanding the reading passage (example 24). This is interesting because the teacher has prepared several activities but allowing students with the activity they are comforted with is also crucial. The last entry of students response is from T4 who shares that his class is enthusiastic in doing the activity with a poster they prepare (example 25).

Example 23 (T1):

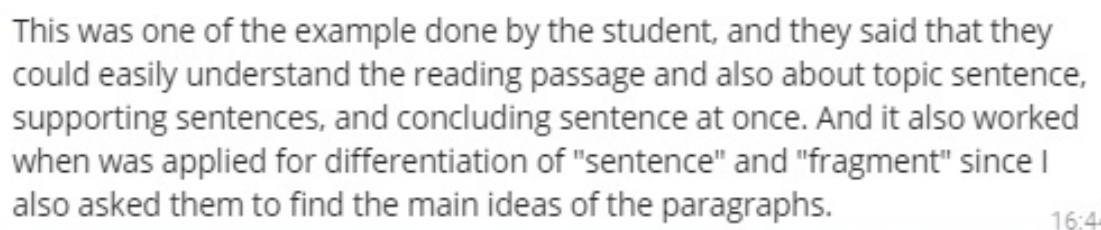


Example 24 (T6):

Here is what I have done in my class. I usually ask the students what kinds of activity they prefer to do each meeting. In fact, I have prepare several activities for them. One of the class I teach, PIH 3, prefer to have grouping activity where they can work independently in understanding the reading passage. Here are the procedures of the activity:

Example 25 (T4):

Last Tuesday on Islamic Dakwa, still based on groups, I asked students to make a poster (related to the text). Since they are students of FDK, they are enthusiastic in doing it. Based on the poster, they have to make at least

\subsection{Teacher and students relationship}

Teachers should build a positive relationship with students so they can feel free and safe to learn. If the bond of between teacher and student is good, it will support them to be productive. This aspect may relate to other categories such as students' response and teaching strategy. Understanding what students comfort with and prefer as written by T6 in Example 24 that reflects a teacher and students relationship. It is an example of understanding students problem, confusion, even fear in the classroom. Another entry that describes a positive teacher and students relationship is shown in example 23 which is written by T1. When the students say that they can easily understand the material, it shows that the teacher cares about the students. Such caring creates a positive atmosphere for learning.

\subsection{Classroom Interaction}

The interaction made in the class during the learning process will contribute to learning success. Dynamic interaction makes a positive environment for students. Thus, teachers should make various activity and interaction in the class. T6 gives an example of interaction in the form of group interaction and whole class interaction (example 26). The individual activity is reflected in scanning and skimming activity. The group interaction is described when the student's groups are discussing the paragraph. The class interaction happens when the group is presenting the paragraph to the whole class members. Another class interaction is what T5 has written stating that two selected students are assigned to display their paragraph and the whole class members identify the paragraph in terms of grammatical mistake and give feedback to improve the paragraph. This activity involves more students because they give more comments and feedbacks while the teacher observes the discussion (example 26). The last example of interaction is described in a class where students work in a group and do sequence activities started by making posters, writing sentences that describes the posters, doing correction, and presenting what they have done (example 27). 
Example 25 (T6):
passage. Here are the procedures of the activity:
1. I group them based on the number of the paragraph.
2. Each group will be responsibe for one paragraph.
3. Each group has 15 minutes to identify the difficult vocabulary and find the meaning. Then, they have to understand the paragraph preparing to presentation session.
4. Then, each group has 6 minutes to present what the passage is about. The time includes question-answer session.
5. The teacher should be carefully manage the time limit in order not to waste the time.
6. The rest of the time will be used for scanning and skimming exercise.

\title{
Example 26 (T5):
}

\begin{abstract}
Yesterday, as those two students were ready with their requested paragraphs, we displayed the paragraph on the slide, discussed the grammatical mistakes, and shared helpful feedback and other language aspects for improvement. The Ss commented on many things, I just observed their discussion. Are there any grammar or spelling problems? Can you help me to edit them? Are there enough details? Where do we need to add more? Does the paragraph cover topic s., supporting ss., and concluding s.? etc. I'll show their work later, Bapak Ibu, as I'm not with my computer now. hat's all.

After dealing with their paragraph assignment, I continued the discussion on simple past, connectors, and pronouns for the purpose of recount paragraph. Again, I requested two Ss to serve as the volunteer preparing a recount paragraph. However, this time I didn't decide the title of their paragraph. I just requested them to write their past interesting experience or trip, at least 10 sentences. I was planning to do the same way for feedback.
\end{abstract}

\section{Example 27 (T4):}

\begin{abstract}
Last Tuesday on Islamic Dakwa, still based on groups, I asked students to make a poster (related to the text). Since they are students of FDK, they are enthusiastic in doing it. Based on the poster, they have to make at least 5sentences describing it. In the last 15 minutes of the class, I asked them to do peer correction on the sentences they wrote.
\end{abstract}

\subsection{Teacher decision making}

The decision made by a teacher determines the success of a teaching-learning process. What teacher decides should be based on what is suitable for the students. This category is also related to the previous category such as teaching approaches and strategy and teacher students relationship. T4 decides to teach nominal and verbal sentences by introducing the structure such as subjects, verbs, even objects. He believes that teaching the material is essential even in the simplest way (example 28). This is different from $\mathrm{T} 1$ who teaches the descriptive text and asks students to do correction on friend's work. She argues that such activity is vital to provide insight for students with error recognition which becomes part of the TOEFL test (example 29). TOEFL test is one of the learning, and some materials of it are inserted in the final test of the course. The other teacher, T3, decides to focus on vocabulary activity due to its effect on students reading comprehension. She cares and focuses on the need for vocabulary acquisition 
through the identification of the part of speech (example 30). Feedback of what a teacher has decided is shown in example 31 questioning how the teacher connects the vocabulary activity with the book's orientation such as TOEFL preparation. Such feedback strengthens and examines what a teacher has decided for his or her class. Thus, it can also be used as a selfevaluation for the teacher.

Example 28 (T4):

In my mind, it is important to make students familiar with SPOK, nominal and verbal sent. I started giving the material in the 2 nd class, eventhough it is in its simplest way. For ex, I asked them to underline which one is subj,pred of a sentence.

Example 29 (T1):

Yesterday and today, we had writing exercise about descriptive text. On the learning process, I asked the students to read and correct their friend's work, this aimed to give them sight about eror recognition which also includes in TOEFL

Example 30 (T3):

it will be closely related, sir, for detail effect in the term of reading comprehension. the session of reading really request vocabulary acquisition, and $\mathrm{i}$ left something that the method in the end of the session also require student'ability to learn part of speech

the part of speech,in case is really important to solve reading session and session 2 ( structure)

Example 31 (T5):

I have a question, anyway. As English 2 has been also designed for TOEFL preparation, how will you link this method with the book's orientation, i.e. TOEFL? Thanks, Bu.

\subsection{Specific "problem" student}

Among the reflection entries written by teachers, no specific reflection tells specifically about a "problem" student. The teachers write mostly on how do they teach in the class. There is an entry telling that particular class has its level and situation that need special treatment in writing (Example 32). However, when a teacher tries to clarify what kind of treatment she employs (example 33), she does not answer it and prefer to obtain feedback for the vocabulary quiz she proposes (example 34). Again, this is not about specific problem student but about specific class in which the detail is not explicitly described. 
Example 32 (T3):

depend on the class level and situation

may be, some classes needed more special treatment in their writing

moment, hehehe, so the writing session would be longer,.

Example 33:

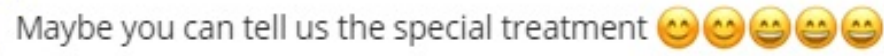

Example 34 (T3):

i need the feedback for the quizzes, first mam,

please ${ }^{\prime \prime}$, hlus

\subsection{Problem on writing reflection entries}

The teachers face some problems when they have to write reflection entries. First, time is the biggest problem faced by those teachers. They argue that they need more time to reply to chat entries. Writing or typing an entry in English with an excellent organisation, comprehensive content, and the whole idea requires more time and thought. By doing so, some teachers consider that the entry and feedbacks typed will not judge and offend others. Also, when the teachers have more class to teach, they have limited time to write the reflection.

Meanwhile, they have to write entries after the class has finished. For some teachers, typing a reflection entry chat is different from typing a simple chat message with others. This fact is surprising considering that most of them are active users of WhatsApp in their daily life. A reason is revealed that writing an entry in English is the same as writing for academic purpose, so they consider that they have to type the entry formally.

Secondly, an incomplete reflection entry becomes a problem for some teachers. When the entry is not written completely, it can lead to different understanding even mis-understanding. When teachers want to confirm, clarify or ask questions, they have to write in English that needs more thoughts. Thirdly, some teachers admit that they feel lazy to write and explain the entry in detail. This condition causes those teachers to not go along with the chat so that they are late to give a response. If they are late, they prefer to keep silent or ignore the discussion. Fourthly, unfamiliar topics make some teachers cannot give a response and comments toward the others' reflection. A teacher feels that such condition makes him "blank" and cannot give a comment or even suggest as feedback.

\section{Discussion}

The results of this study show that teachers benefit the reflective practice mediated by WhatsApp group application. However, this study reveals that the use of a platform as reflection tool is not as smooth as other studies, e.g. (Newhouse, Lane, \& Brown, 2007) who find that a digital tool can assist the reflection of teachers' practice in the classrooms. Some problems and considerations need to addressed in this study. Teachers write reflective entries on their classroom practice and the problem that they face. Writing reflection through an online group 
has also been revealed by Tsang (2011) describing that online group discussion provides insights into the learning experience perception. To further investigate their classroom practices and experiences, it requires to enter (Connelly \& Clandinin, 2006) three-dimensional space of temporality, sociality, and place where teachers tell their stories through reflection entries. The reflection done is about how they spend in the classroom, the comtemplation about the life and experiences with the students. The temporality constitutes to teachers' past experience, current practice, and future plan. In this context, teachers employ their past learning experience as the basis in designing and planning the learning. Writing reflection has helped teachers to examine their classroom practices through what they assume and believe to increase their skills in teaching which include class management dealing with how they organise students, teaching approaches and strategies, and decision making of how to gain success for students' learning. This is all about what teachers interprete to do since they are the only know what is best for their students. Through this activity, teachers may evaluate teaching and learning aspects such as their teaching, students, and they that will be useful for improving practice (Richards \& Farrell, 2005). The present practice predicts and makes better teachers' future teaching or action, whether they have sufficient time or not, whether their students can understand the materials they deliver or not. By doing such critical reflection on practice, teachers are aware of what they do and responsible for what they act by articulating their beliefs, assumptions and values about teaching and learning practice with their combined past experience and knowledge integration (Farrell, 2013).

Socialty is about teachers' personal conditions that denote feelings or attitudes toward certain events, and teachers' social conditions that cover the institution's administration, policy, and community (Clandinin \& Connelly, 2000). How teachers consider students' comfort by understanding their problem, confusion, and fear in the classroom has shown teachers' personality. The materials that teachers deliver such as error recognition, vocabulary activity, and reading comprehension consider the course objectives in which all of those materials are orientated to prepare students with Test of English as a Foreign Language (TOEFL). Students are required to reach a particular score of TOEFL as a graduation requirement. Passing the TOEFL test is obligatory for all students, and it has become an institution policy. Understanding how the institution of this context struggle with what it aims for is important for anyone seeking to achieve certain teaching goals. In teaching, the teacher cannot separate the materials taught with the goals and objectives, either learning context or institutional context. It is because teachers are also influenced and shaped by their social and political context (Chien, 2013).

Place refers to where the stories occur. Clandinin \& Connelly (1996) mention two main places for teachers namely the classroom and communal places. Teachers are free to tell and live their story on what happened in the classroom. Some teachers have mentioned activities that can be done and some activities that cannot be done in the classroom such as the use of an online dictionary. Such a policy has invited other teachers to question and come with a solution. Of course, those allow the use of online dictionary may be contradictory outside the classroom because the institution has decided a policy stating that every student gets a dictionary book in which the payment is included in every students' tuition fee. This condition has proved how the classroom has become a free, secret, and personal place where teachers can feel secure to determine their practical knowledge and make the decision independently (Xu \& Liu, 2009). 


\subsection{Analysing online reflection collaboration and its barriers}

Discussing entries of classroom practice is the core activity that teachers do through WhatsApp application. For a reflectice practice purpose, it is necessary to articulate the space and action either online or offline since the attention to the design and delivery impact differently to teachers (Ribas \& Perine, 2016). This practice is in the form of collaboration among teachers so that they can challenge, support, a complement for any limitation they have (Farrell, 2008a). Most of the teachers consider that this WhatsApp-mediated teachers' reflection is useful and helpful for gaining inspiration for teaching techniques and increasing their professional development. They engage in an online conversation to evaluate and get feedback and input of what they have done in the classroom from other teachers. This is what collaboration in reflective practice should be, looking back to the teaching process, making a judgement of it, and changing it in terms of innovation and knowledge (Valli, 1997). The online collaboration through the online platform of WhatsApp group becomes an online community where teachers can share knowledge, experience or teaching practice; make suggestions to others; evaluate teaching methods; and support or challenge their claim (Burhan-Horasanlı \& Ortaçtepe, 2016). The shared teaching practice is discussed and, and they get feedback for the teaching practice they do from other teachers considering that most of the reflection entries are about teaching practices and strategies. The feedback is used to evaluate and strengthen a teacher's belief because what he or she believes is good may not be effective to acquire the expected learning outcomes. Such consideration needs inputs and suggestions that become options for teaching improvement. Kabilan's (2007) study reveals the benefits of collaborative reflective rather than individual reflective procedure by stating that "when shared with other members of a learning community, the individual's thoughts and experiences are collaboratively maximized" (p.698). Crow \& Smith (2005) argue that sharing teaching practice and experience give teachers chances to both deconstruct and reconstruct meanings so they can alter their belief and understanding in order to make a change of their future teaching practice. It confirms that teachers' participation in online communities becomes crucial needs that support professional development (Satar \& Akcan, 2018). However, it must be pointed out that reflection sharing here should not aim to provide "correct" beliefs and practices. Instead, it promotes teachers' awareness of beliefs and practices that enable them to examine the existing gaps (Farrell, 2006, p.88).

Unfortunately, even those teachers admit the use of this collaborative reflection, and they think that making a direct meeting with other teachers is essential. Most of them consider that a direct meeting can bridge gap and misunderstanding among them. Such reason actually can be clarified through WhatsApp chat that they use because they are active users of the application, but they do not do it. Dealing with ths situation, Enochsson (2018) aware of the differences that happen in individual, where some may develop their thoughts well and some others may feel less if the discussion setting is online. Some teachers admit that they do not understand the topic of the chat due to some reasons such as they do not experience it before. Dealing with this problem, it is also revealed that they have limited time to write the entries. The time limit has become a problem faced by the teacher in keeping journal entries for reflection (Chien, 2013). Besides, the barrier is also because they have to write reflection entries in English. Writing reflection entries in English requires more thoughts for not only the idea but also the grammar aspect. The problem is not simply because some people feel difficult to write a reflection in narrative form (Barkhuizen \& Wette, 2008). To gain more benefits of online reflection, teachers should interact 
with each other like what they do in their daily communication without recognising that the chat interaction is a reflective practice. Flexibility should be set in terms of allowing teachers to communicate in their language so they will not feel bothered and reluctant to participate and engage in the reflection chat entries. This study confirm what Enochsson (2018) reveals that not all individuals can optimally develop their thoughts whether it is in oral or written modes. The discussion does not always guide individuals' reasoning development in whatever online or offline settings. Finally, it is imperative to set up an online environment that let teachers, as reflective practitioners, interact and share with colleagues to construct knowledge and insights that beneficial for teacher professional development.

\section{Conclusion}

This study explores language teachers' reflective practice mediated by WhatsApp application and addresses the topics mostly reflected in the classroom practice among the eight topics proposed by (Brock, Wong, \& Yu, (1993), and the problems and challenges faced. The findings reveal that among a total of 537 entries of chats written, the most common topic of reflection entries is about general teaching approaches. Time restraint and writing chats in English become significant problems of the reflective practice. The practice has provided an online environment that lets teachers interact and share with colleagues to construct knowledge and evaluate teaching practice that beneficial for teacher professional development.

This is a qualitative case study of reflective practice based on the experience of teachers in a university in Indonesia. The findings may give benefit language programs or teacher professional development by suggesting teachers to collaboratively learn from and with others in online reflection but they cannot be generalised to bigger teacher's populations in more numbers of the university. The writing of reflection mediated by WhatsApp application gives options for the reflective practice implementation. Teachers have gained benefits from online reflection collaboration with other teachers, but most of them take into account the need for online reflection setting that gives those teachers freedom including to use the language that they comfort with while writing a reflection. So, such online reflection can facilitate teachers with interaction and collaboration that uphold collegiality and mutual support within the professional learning community.

\section{References}

Abednia, A., Hovassapian, A., Teimournezhad, S., \& Ghanbari, N. (2013). Reflective journal writing: Exploring in-service EFL teachers' perceptions. System, 41(3), 503-514. https://doi.org/10.1016/j.system.2013.05.003

Anwaruddin, S. M. (2015). Teacher professional learning in online communities: toward existentially reflective practice. Reflective Practice, 16(6), 806-820. https://doi.org/10.1080/14623943.2015.1095730

Bain, J. D., Ballantyne, R., Packer, J., \& Mills, C. (1999). Using Journal Writing to Enhance Student Teachers' Reflectivity During Field Experience Placements. Teachers and Teaching, 5(1), 51-73. https://doi.org/10.1080/1354060990050104

Barkhuizen, G., \& Wette, R. (2008). Narrative frames for investigating the experiences of language teachers. System, 36(3), 372-387. https://doi.org/10.1016/J.SYSTEM.2008.02.002 
Borg, S. (2001). The research journal: a tool for promoting and understanding researcher development. Language Teaching Research, 5(2), 156-177. https://doi.org/10.1177/136216880100500204

Brock, M., Wong, M. M. W., \& Yu, B. (1993). Collaborative Dairy Keeping. In D. Freeman \& Steve Cornwell (Ed.), New Ways in Teacher Education. Virginia: TESOL Inc.

Burhan-Horasanl, E., \& Ortaçtepe, D. (2016). Reflective practice-oriented online discussions: A study on EFL teachers' reflection-on, in and for-action. Teaching and Teacher Education, 59, 372-382. https://doi.org/10.1016/J.TATE.2016.07.002

Chien, C. W. (2013). Analysis of a language teacher's journal of classroom practice as reflective practice. Reflective Practice, 14(1), 131-143. https://doi.org/10.1080/14623943.2012.732951

Clandinin, D. J., \& Connelly, F. M. (2000). Narrative inquiry: Experience and story in qualitative research. San Francisco: Jossey-Bass.

Clandinin, D. J., \& Connelly, F. M. (1996). Teachers' Professional Knowledge Landscapes: Teacher Stories--Stories of Teachers--School Stories--Stories of Schools. Educational Researcher, 25(3), 24-30. https://doi.org/10.3102/0013189X025003024

Connelly, F. M., \& Clandinin, D. J. (2006). Narrative inquiry. In \& P. B. E. J. L. Green, G. Gamilli (Ed.), Complementary methods for research in education (3rd ed., pp. 375-385). Mahwah, NJ: Erlbaum.

Creswell, J. W. (2009). Research design: Qualitative, quantitative, and mixed methods approach (3rd ed.). Thousand Oaks, California: Sage Publications.

Crow, J., \& Smith, L. (2005). Co-teaching in higher education: reflective conversation on shared experience as continued professional development for lecturers and health and social care students. Reflective Practice, 6(4), 491-506. https://doi.org/10.1080/14623940500300582

Dewey, J. (1933). How we think, a restatement of the relation of reflective thinking to the educative process. Boston, New York: D.C. Heath and company.

East, M. (2014). Mediating pedagogical innovation via reflective practice: a comparison of preservice and in-service teachers' experiences. Reflective Practice, 15(5), 686-699. https://doi.org/10.1080/14623943.2014.944128

Ellis, A., \& Phelps, R. (2000). Australasian journal of educational technology. Australasian Journal of Educational Technology, 16(1). Retrieved from https://ajet.org.au/index.php/AJET/article/view/1820/885

Enochsson, A.-B. (2018). Reflective discussions in teacher training: A comparison between online and offline discussions of course literature in a class of pre-service teachers. Education and Information Technologies, 23(1), 303-319. https://doi.org/10.1007/s10639017-9602-5

Farrell, T. S. (2016). Anniversary article: The practices of encouraging TESOL teachers to engage in reflective practice: An appraisal of recent research contributions. Language Teaching Research, 20(2), 223-247. https://doi.org/10.1177/1362168815617335

Farrell, T. S. C. (2006). Reflective Practice in Action: A Case Study of a Writing Teacher's Reflections on Practice. TESL Canada Journal, 23(2), 77-90. https://doi.org/10.18806/tesl.v23i2.56

Farrell, T. S. C. (2008a). reflective practice in the professional development of teachers of adult 
English language learners. CAELA Network, (October), 1-4. Retrieved from www.cal.org/caelanetwork

Farrell, T. S. C. (2008b). Critical incidents in ELT initial teacher training. ELT Journal, 62(1), 310. https://doi.org/10.1093/elt/ccm072

Farrell, T. S. C. (2012). Reflecting on Reflective Practice: (Re)Visiting Dewey and Schön. TESOL Journal, 3(1), 7-16. https://doi.org/10.1002/tesj.10

Farrell, T. S. C. (2013). Reflective Practice in ESL Teacher Development Groups From Practices to Principles. New York, NY: Palgrave Macmill.

Ford, K. (2016). The taped monologue as narrative technique for reflective practice. ELT Journal, 70(3), 253-260. https://doi.org/10.1093/elt/ccv079

Jones, M., \& Ryan, J. (2014). Learning in the practicum: engaging pre-service teachers in reflective practice in the online space. Asia-Pacific Journal of Teacher Education, 42(2), 132-146. https://doi.org/10.1080/1359866X.2014.892058

Kabilan, M. K. (2007). English Language Teachers Reflecting on Reflections: A Malaysian Experience. TESOL Quarterly, 41, 681-705. https://doi.org/10.2307/40264402

Kabilan, M. K., Adlina, W. F. W., \& Embi, M. A. (2011). Online collaboration of English language teachers for meaningful professional development experiences. English Teaching: Practice and Critique, 10(4), 94-115. Retrieved from http://education.waikato.ac.nz/research/files/etpc/files/2011v10n4art6.pdfpp.94-115

Martínez, J. M. G. (2018). How effective is collaborative reflective practice in enabling cognitive transformation in English language teachers? Reflective Practice, 19(4), 427-446. https://doi.org/10.1080/14623943.2018.1479688

Mitton-Kükner, J., Nelson, C., \& Desrochers, C. (2010). Narrative inquiry in service learning contexts: Possibilities for learning about diversity in teacher education. Teaching and Teacher Education, 26(5), 1162-1169. https://doi.org/10.1016/J.TATE.2010.01.001

Murphy, J. M. (2014). Reflective teaching: Principles and practices. In \& M. A. S. M. CelceMurcia, D. M. Brinton (Ed.), Teaching English as a second or foreign language (4th ed., pp. 613-628). Boston, MA: National Geographic Learning.

Murray, A. (2010). Empowering Teachers through Professional Development. English Teaching Forum, 48(1), 2-11.

Musahrain. (2016). Developing Android-Based Mobile Learning as a Media in Teaching English. Proceeding The 2nd International Conference On Teacher Training and Education Sebelas Maret University, 307-313.

Nambiar, R. M. K., \& Thang, S. M. (2016). Examining Malaysian teachers' online blogs for reflective practices: towards teacher professional development. Language and Education, 30(1), 43-57. https://doi.org/10.1080/09500782.2015.1071386

Newell, S. T. (1996). Practical inquiry: Collaboration and reflection in teacher education reform. Teaching and Teacher Education, 12(6), 567-576. https://doi.org/10.1016/S0742051X(96)00001-7

Newhouse, C. P., Lane, J., \& Brown, C. (2007). Relecting on Teaching Practices Using Digital Video Representation in Teacher Education. Australian Journal of Teacher Education, 32(3). https://doi.org/10.14221/ajte.2007v32n3.5 
Oakley, G., Pegrum, M., \& Johnston, S. (2014). Introducing e-portfolios to pre-service teachers as tools for reflection and growth: lessons learnt. Asia-Pacific Journal of Teacher Education, 42(1), 36-50. https://doi.org/10.1080/1359866X.2013.854860

Orlova, N. (2009). Video Recording as a Stimulus for Reflection in Pre-Service EFL Teacher Training. English Teaching Forum, 30-35. Retrieved from http://files.eric.ed.gov/fulltext/EJ923452.pdf

Pack, M. (2014). Practice journeys: using online reflective journals in social work fieldwork education. Reflective Practice, $15(3), \quad 404-412$. https://doi.org/10.1080/14623943.2014.883304

Pedro, J., Abodeeb-Gentile, T., \& Courtney, A. (2012). Reflecting on Literacy Practices: Using Reflective Strategies in Online Discussion and Written Reflective Summaries. Journal of Digital Learning in Teacher Education, 29(2), 39-47. https://doi.org/https://doi.org/10.1080/21532974.2012.10784703

Pennington, M. C. (1992). Reflecting on teaching and learning: a development focus for the second language classroom. In \& S. H. J. Flowerdew, M. Brock (Ed.), Perspectives on Second Language Teacher Education. Hong Kong: City Polytechnic of Hong Kong.

Phillips, P. (2008). Professional Development as a Critical Componenet of Continuing Teacher Quality. Australian Journal of Teacher Education, $33(1), \quad 8$. https://doi.org/10.14221/ajte.2008v33n1.3

Pollard, A. (2015). Increasing awareness and Talk time through free messaging apps. English Teaching Forum, 25-32.

Ribas, C., \& Perine, C. M. (2016). Online discussion forums: a tool for stimulating language teachers' interaction and reflection | FORMAMENTE. Retrieved August 22, 2019, from https:/formamente.guideassociation.org/online-discussion-forums-a-tool-for-stimulatinglanguage-teachers-interaction-and-reflection/

Richards, J.C., \& Farrell, T. S. C. (2005). Professional development for language teachers. New York, NY: Cambridge University Press.

Romano, M. E. (2008). Online discussion as a potential professional development tool for firstyear teachers. Technology, Pedagogy and Education, 17(1), 53-65. https://doi.org/10.1080/14759390701847591

Satar, H. M., \& Akcan, S. (2018). Pre-service EFL teachers' online participation, interaction, and social presence. Language Learning \& Technology, 22(1), 157-183. Retrieved from https://www.lltjournal.org/item/3037

Tsang, A. K. L. (2011). Online reflective group discussion-connecting first year undergraduate students with their third year peers. Journal of the Scholarship of Teaching and Learning, 11(3), 58-74. Retrieved from www.iupui.edu/ josotl

Valli, L. (1997). Listening to other voices: A description of teacher reflection in the United States. Peabody Journal of Education, 72(1), 67-88. https://doi.org/10.1207/s15327930pje7201_4

Xu, S., \& Connelly, F. M. (2009). Narrative inquiry for teacher education and development: Focus on English as a foreign language in China. Teaching and Teacher Education, 25(2), 219-227. https://doi.org/10.1016/J.TATE.2008.10.006

$\mathrm{Xu}, \mathrm{Y}$. (2014). Becoming researchers: A narrative study of Chinese university EFL teachers' 
research practice and their professional identity construction. Language Teaching Research, 18(2), 242-259. https://doi.org/10.1177/1362168813505943

Xu, Y., \& Liu, Y. (2009). Teacher Assessment Knowledge and Practice: A Narrative Inquiry of a Chinese College EFL Teacher's Experience. TESOL Quarterly, 43(3), 492-513. https://doi.org/10.1002/j.1545-7249.2009.tb00246.x

Yeung, K. (2013). WhatsApp Processed A Record 18 Billion Messages On Last Day of 2012. Retrieved from https://thenextweb.com/insider/2013/01/02/whatsapp-processed-record18-billion-messages-on-last-day-of-2012/\#gref

Yin, R. K. (2003). Case Study Research: Design and Methods. Thousand Oaks, California: Sage Publications. 